Brit. Heart f., 1966, 28, 546.

\title{
Artificial Pacing by Electrode Catheter for Heart Block or Asystole Complicating Acute Myocardial Infarction
}

\author{
E. J. EPSTEIN, N. COULSHED, C. S. MCKENDRICK, JOAN CLARKE^, AND W. E. KEARNS \\ From the Liverpool Regional Cardiac Centre, Sefton General Hospital, Liverpool, 15
}

Complete or partial heart block complicating acute myocardial infarction is relatively uncommon, occurring in from 2 to 7 per cent of patients. In 8 published series of patients with acute myocardial infarction, details were available of 2,270 patients. Heart block developed in $106(4.6 \%)$; it was complete in $63(2.7 \%)$ and incomplete in $43(1.9 \%)$ (Master, Dack, and Jaffe, 1938; Rosenbaum and Levine, 1941; Mintz and Katz, 1947; Goldman, 1950; Johnson and Miner, 1958; Imperial, Carballo, and Zimmerman, 1960; Blondeau, Rizzon, and Lenègre, 1961; Courter, Moffat, and Fowler, 1963). However, previous estimates of its frequency may need to be revised now that continuous electrocardiographic monitoring of patients with myocardial infarction is more frequently carried out (Robinson, Sloman, and McRae, 1964; Julian, Valentine, and Miller, 1964; Day, 1965).

Studies of the prognostic significance of acute heart block in myocardial infarction show that the mortality rate is high, ranging from 30 to 100 per cent. Table I shows the mortality in 11 reports. Out of 270 patients, $126(47 \%)$ died within a month of the myocardial infarction. The mortality for complete heart block $(54 \%)$ was greater than for incomplete block $(34 \%)$. Patients die either suddenly, presumably from asystole or ventricular fibrillation, or from progressive cardiogenic shock and cardiac failure.

There has been increasing interest in dysrhythmias in acute myocardial infarction since it has been shown that they are a common cause of death, particularly in the first 3 to 7 days (Brown et al., 1963; Julian et al., 1964; Day, 1965). Heart block develops during the early stages of an acute infarction: one-third within 24 hours; two-thirds within 72 hours; and over 90 per cent in the first week (Master et al., 1938; Gilchrist, 1958; Blondeau

Received October 22, 1965.

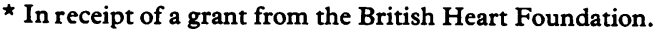

et al., 1961; Courter et al., 1963). It lasts from a few hours up to several days, and in those patients who survive permanent heart block is rarely observed.

Conventional treatment with atropine or sympathomimetic drugs such as ephedrine and adrenaline has been of small benefit especially in seriously ill patients. Intravenous infusion of isoprenaline was first used by Gale and Enfroy (1959) in the treatment of Stokes-Adams seizures and heart block complicating myocardial infarction, and Vogel (1961) successfully used it in 3 patients with complete heart block during an acute myocardial infarction. Other authors have found it of no benefit (Samet, Jacobs and Bernstein, 1963; Bruce et al., 1965).

Steroids were reported to be of value in acute heart block with infarction by Prinzmetal and Kennamer (1954) and by Phelps and Lindsay (1957).

More recently Dall and Buchanan (1962) and Dall (1964) have reported good results with parenteral hydrocortisone in restoring sinus rhythm in complete heart block complicating acute myocardial infarction.

In the past five years implanted artificial pacemakers have been increasingly used for patients with Stokes-Adams attacks and chronic complete heart block (Abrams, Hudson, and Lightwood, 1960; Portal et al., 1962; Chardack et al., 1963; Landegren and Biörck, 1963). The development of the intravenous electrode catheter by Furman and Robinson (1958) provided a relatively easy method for emergency and short-term artificial pacing, and an improved bipolar electrode catheter was introduced by Parsonnet et al. (1962). The first patient with complete heart block in acute myocardial infarction treated by artificial pacing with an electrode catheter was referred to by Hurwitt in a paper by Levowitz, Ford, and Smith (1960). Further case reports of electrode catheter pacing for this condition have since appeared (Zucker et al., 1963; 
Artificial Pacing for Heart Block Complicating Myocardial Infarction

TABLE I

DEATHS WITHIN ONE MONTH OF ACUTE MYOCARDIAL INFARCTION

\begin{tabular}{|c|c|c|c|c|c|c|c|}
\hline Reference & \multicolumn{2}{|c|}{$\begin{array}{l}\text { Incomplete heart } \\
\text { block (Grade II) }\end{array}$} & \multicolumn{2}{|c|}{$\begin{array}{l}\text { Complete heart } \\
\text { block (Grade III) }\end{array}$} & \multicolumn{3}{|c|}{$\begin{array}{l}\text { Total no. of patients (Grade II } \\
\text { and Grade III) with heart block }\end{array}$} \\
\hline & No. & Deaths & No. & Deaths & No. & Deaths & $\%$ Deaths \\
\hline 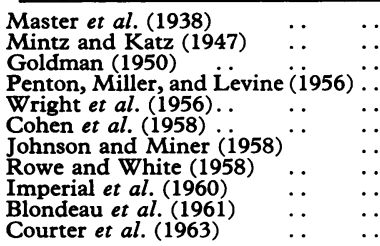 & $\begin{array}{r}6 \\
11 \\
2 \\
\frac{1}{55} \\
\frac{3}{5} \\
12 \\
3\end{array}$ & $\begin{array}{l}2 \\
6 \\
0 \\
\frac{0}{22} \\
\frac{1}{1} \\
0 \\
1\end{array}$ & $\begin{array}{r}6 \\
5 \\
2 \\
47 \\
9 \\
13 \\
7 \\
38 \\
5 \\
26 \\
15\end{array}$ & $\begin{array}{r}4 \\
5 \\
1 \\
21 \\
6 \\
10 \\
2 \\
16 \\
4 \\
18 \\
6\end{array}$ & $\begin{array}{r}12 \\
16 \\
4 \\
47 \\
9 \\
68 \\
10 \\
38 \\
10 \\
38 \\
18\end{array}$ & $\begin{array}{r}6 \\
11 \\
1 \\
21 \\
6 \\
32 \\
3 \\
16 \\
5 \\
18 \\
7\end{array}$ & $\begin{array}{l}50 \\
69 \\
25 \\
45 \\
66 \\
47 \\
30 \\
42 \\
50 \\
47 \\
39\end{array}$ \\
\hline Total $\quad$. & 97 & $\begin{array}{c}33 \\
(34 \%)\end{array}$ & 173 & $\begin{array}{c}93 \\
(54 \%)\end{array}$ & 270 & 126 & 47 \\
\hline
\end{tabular}

Note: Patients with Grade I heart block, i.e. prolongation of P-R interval beyond 0.22 sec. have been excluded from the series.

Delman, Schwedel, and Escher, 1963; Robinson et al., 1964; Day, 1965; DeSanctis, 1963; Samet et al., 1963; Sowton, 1964a). The largest series is that of Bruce et al. (1965) who described 9 of their own patients and collected information about a further 22. The total reported experience of this method of treatment consists of less than 50 patients.

The management of heart block in acute myocardial infarction is still controversial and the indications for artificial pacing have not been defined. We present here our experience with a group of 9 patients treated by artificial pacing with an intravenous electrode catheter for heart block or asystole complicating myocardial infarction. A tenth patient is also reported in whom complete heart block developed as a terminal arrhythmia following resuscitation for asystolic cardiac arrest and where artificial pacing was attempted. Cardiac output studies were carried out in 4 patients by an external counting technique using radio-iodinated human serum albumin (Veall and Vetter, 1958).

The purpose of this paper is to try to define the indications for artificial pacing if heart block complicates acute myocardial infarction. The individual case reports follow and the main features are summarized in Table II.

\section{CASE Histories}

Patient 1 (E.D.). A 60-year-old man was recovering from his third myocardial infarct when he had another bout of severe chest pain and showed an atrial triple rhythm, pericardial friction, and a further rise in serum transaminase levels. Twenty-four hours later he suddenly became unconscious and pulseless. Immediate resuscitation by external cardiac massage and artificial ventilation restored spontaneous heart action after 15 minutes. An electrocardiogram then showed complete heart block with a ventricular rate of 40 a minute and a left bundle-branch block.

$\mathrm{He}$ was given hydrocortisone intramuscularly and after a period of hypotension his condition improved and the blood pressure rose to $88 / 60 \mathrm{~mm}$. $\mathrm{Hg}$, still with complete heart block. Eight hours after the collapse he began to have recurrent Stokes-Adams attacks due to periods of ventricular asystole. Because of failure to respond to medical treatment over a further 7 hours, a unipolar electrode catheter was passed to the apex of the right ventricle and artificial pacing established at a rate of 80 a minute. There was rapid improvement in his condition and the blood pressure rose from 80/50 before pacing to $120 / 80 \mathrm{~mm}$. $\mathrm{Hg} 30$ minutes after pacing began. The Stokes-Adams seizures ceased and he remained well until the fourth day of pacing when he began to have further recurrent Stokes-Adams attacks due to ventricular asystole. Repeated attempts were made to re-establish pacing by repositioning the catheter but without success.

Because of the critical condition of the patient it was decided to implant an internal pacemaker, and this was performed as an emergency procedure and satisfactory pacing was established at a rate of 70 a minute. After initial improvement he developed progressive hypotension and left ventricular failure and died 36 hours after operation. There was no necropsy.

Comments. This patient developed complete heart block after his fourth myocardial infarct. His condition was critical because of recurrent Stokes-Adams attacks and progressive circulatory failure. Artificial pacing produced an immediate clinical improvement, but failure of catheter pacing developed for technical reasons and an internal pacemaker was implanted. Despite satisfactory pacing the patient died, as with a severely damaged myocardium he was unable to withstand the stress of major surgery. After further experience in the use of electrode catheters we now feel 
TABLE II

CLINICAL DETAILS OF 9 PATIENTS TREATED BY ELECTRODE CATHETER PACING

\begin{tabular}{|c|c|c|c|c|c|c|c|c|c|c|c|}
\hline $\begin{array}{l}\text { Patient } \\
\text { no., sex, } \\
\text { and age }\end{array}$ & $\begin{array}{l}\text { Site of } \\
\text { infarct }\end{array}$ & $\begin{array}{l}\text { Degree } \\
\text { of block }\end{array}$ & $\begin{array}{l}\text { Heart } \\
\text { rate } \\
\text { per min. }\end{array}$ & $\begin{array}{c}\text { Systolic } \\
\text { blood } \\
\text { pressure } \\
(\mathrm{mm} . \mathrm{Hg})\end{array}$ & $\begin{array}{c}\text { Indication } \\
\text { for } \\
\text { pacing }\end{array}$ & $\begin{array}{l}\text { Steroids } \\
\text { before } \\
\text { or after } \\
\text { pacing }\end{array}$ & $\begin{array}{c}\text { Time of } \\
\text { onset } \\
\text { of } \\
\text { block }\end{array}$ & $\begin{array}{l}\text { Time of } \\
\text { pacing } \\
\text { after } \\
\text { block }\end{array}$ & $\begin{array}{c}\text { Duration } \\
\text { of } \\
\text { pacing }\end{array}$ & $\begin{array}{l}\text { Time } \\
\text { catheter } \\
\text { in situ }\end{array}$ & Outcome \\
\hline $1 M 60$ & $\begin{array}{l}\text { Old } \\
\text { anterior } \\
\text { and } \\
\text { posterior, } \\
\text { recent } \\
\text { posterior }\end{array}$ & $\begin{array}{r}\text { Com- } \\
\text { plete }\end{array}$ & 40 & 70 & $\begin{array}{l}\text { Stokes- } \\
\text { Adams } \\
\text { seizures, } \\
\text { shock }\end{array}$ & $\begin{array}{l}\text { Before } \\
\text { (I.M.) }\end{array}$ & $24 \mathrm{hr}$. & $15 \mathrm{hr}$. & 5 dy. & $3 \star d y$. & Died in shock \\
\hline 2 F 54 & Anterior & $\begin{array}{c}\text { Com- } \\
\text { plete }\end{array}$ & 30 & N.R. & $\begin{array}{l}\text { Stokes- } \\
\text { Adams } \\
\text { seizures, } \\
\text { shock }\end{array}$ & $\begin{array}{l}\text { Before } \\
\text { (I.V.) }\end{array}$ & $48 \mathrm{hr}$. & $6 \mathrm{hr}$. & $16 \mathrm{hr}$. & $14 \mathrm{dy}$. & $\begin{array}{l}\text { Died in congestive } \\
\text { cardiac failure } 4 \\
\text { mth. later }\end{array}$ \\
\hline $3 M 76$ & Posterior & $\underset{\text { plete }}{\text { Com- }}$ & 44 & 100 & $\begin{array}{l}\text { Left } \\
\text { ventric- } \\
\text { ular } \\
\text { failure }\end{array}$ & $\begin{array}{l}\text { Before } \\
\text { (oral) }\end{array}$ & $7 \mathrm{hr}$. & 4 dy. & 8 dy. & $19 \mathrm{dy}$. & $\begin{array}{l}\text { Sudden death nine- } \\
\text { teenth day }\end{array}$ \\
\hline 4 F 74 & Anterior & Partial & 40 & 75 & $\begin{array}{l}\text { Shock, } \\
\text { left } \\
\text { ventric- } \\
\text { ular } \\
\text { failure }\end{array}$ & $\begin{array}{l}\text { Before } \\
\text { (I.V.) }\end{array}$ & $4 \mathrm{hr}$. & $1 \frac{1}{2} \mathrm{hr}$. & $20 \mathrm{hr}$. & $20 \mathrm{hr}$. & $\begin{array}{l}\text { Sudden death; rup- } \\
\text { tured left ventricle }\end{array}$ \\
\hline $5 \mathrm{M} 68$ & Posterior & Partial & 45 & 110 & $\begin{array}{l}\text { Left } \\
\text { ventric- } \\
\text { ular } \\
\text { failure, } \\
\text { conges- } \\
\text { tive } \\
\text { cardiac } \\
\text { failure }\end{array}$ & $\begin{array}{l}\text { After } \\
\text { (oral) }\end{array}$ & $<48 \mathrm{hr}$. & $2+d y$ & 4 dy. & 8 dy. & $\begin{array}{l}\text { Full recovery; well } \\
3 \text { mth. later }\end{array}$ \\
\hline 6 F 57 & Posterior & $\begin{array}{c}\text { Com- } \\
\text { plete }\end{array}$ & 40 & N.R. & $\begin{array}{l}\text { Shock, } \\
\text { left } \\
\text { ventric- } \\
\text { ular } \\
\text { failure }\end{array}$ & None & $\underset{\text { iate }}{\text { Immed- }}$ & $4 \mathrm{hr}$. & $1 \mathrm{hr}$. & $1 \mathrm{hr}$. & $\begin{array}{l}\text { Died unresponsive } \\
\text { to pacing }\end{array}$ \\
\hline $7 M 41$ & Anterior & $\begin{array}{c}\text { Com- } \\
\text { plete }\end{array}$ & 50 & 70 & $\begin{array}{l}\text { Ventric- } \\
\text { cular } \\
\text { tachy- } \\
\text { cardia, } \\
\text { shock, } \\
\text { left } \\
\text { ventric- } \\
\text { cular } \\
\text { failure }\end{array}$ & Before & $21 \mathrm{hr}$. & $8 \mathrm{hr}$. & $26 \mathrm{hr}$. & $26 \mathrm{hr}$. & Died in shock \\
\hline 8 F 57 & $\begin{array}{l}\text { Old post- } \\
\text { erior, } \\
\text { anterior }\end{array}$ & $\begin{array}{l}\text { Com- } \\
\text { plete }\end{array}$ & 40 & 80 & $\begin{array}{l}\text { Shock, } \\
\text { left } \\
\text { ventric- } \\
\text { ular } \\
\text { failure }\end{array}$ & $\begin{array}{l}\text { Before } \\
\text { (I.V.) }\end{array}$ & $48 \mathrm{hr}$. & $4 \mathrm{hr}$. & $38 \mathrm{hr}$. & $7 \mathrm{dy}$. & $\begin{array}{l}\text { Sudden death elev- } \\
\text { enth day }\end{array}$ \\
\hline 9 F 77 & Posterior & $\begin{array}{c}\text { Partial, } \\
\text { then } \\
\text { com- } \\
\text { plete }\end{array}$ & 40 & N.R. & $\begin{array}{l}\text { Stokes- } \\
\text { Adams } \\
\text { seizures, } \\
\text { shock }\end{array}$ & None & $<4$ dy. & $5 \mathrm{hr}$. & 7 wk. & 7 wk. & $\begin{array}{l}\text { Recovery; perman- } \\
\text { ent pacemaker in- } \\
\text { serted }\end{array}$ \\
\hline
\end{tabular}

* Internal pacemaker for two days.

I.M.= Intramuscular. I.V. = Intravenous. N.R. = Not recordable.

that satisfactory pacing could have been re-established and thoracotomy avoided.

Patient 2 (H.D.). A 54-year-old woman had effort angina for three months. She then developed severe central substernal pain and seven hours later was admitted to hospital. On examination she was in sinus rhythm with a blood pressure of $100 / 70 \mathrm{~mm}$. $\mathrm{Hg}$, an atrial triple rhythm, and basal lung crepitations. An electrocardiogram showed sinus rhythm, right bundle-branch block, and an extensive anterior myocardial infarct. Despite treatment with oxygen, metaraminol, digitalis, and anticoagulants her condition gradually deteriorated with progressive hypotension and left ventricular failure. Forty-eight hours after admission she began to have recurrent Stokes-Adams seizures due to ventricular asystole in association with complete heart block at a rate of 30 to 40 a minute. The blood pressure was so low as to be unrecordable, and on three separate occasions the heart beat was restored by percussing the chest. Intravenous hydrocortisone and pressor agents were of no benefit.

Six hours after the onset of the heart block a bipolar electrode catheter* was passed to the apex of the right ventricle, and artificial pacing was established at a rate of 80 a minute. There was a rapid improvement in her condition and over a period of 40 minutes the blood pressure became recordable and reached $100 / 60 \mathrm{~mm}$. $\mathrm{Hg}$. Sinus rhythm returned 16 hours later and pacing was discontinued, though the pacemaker catheter was left in situ for 14 days. She remained in chronic left ventricular failure throughout her stay in hospital but

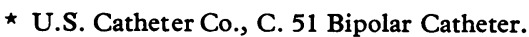


TABLE III

CARDIAC OUTPUT STUDIES BY PRECORDIAL RADIOISOTOPE DILUTION TECHNIQUE

\begin{tabular}{|c|c|c|c|c|c|}
\hline $\begin{array}{l}\text { Patient } \\
\text { No. }\end{array}$ & Time of Study & Rhythm & $\begin{array}{l}\text { Heart rate } \\
\text { per min. }\end{array}$ & $\begin{array}{l}\text { Stroke volume } \\
\text { (ml. per beat) }\end{array}$ & $\begin{array}{l}\text { Cardiac output } \\
\text { (litres per min.) }\end{array}$ \\
\hline $\begin{array}{l}3 \\
5 \\
6\end{array}$ & $\begin{array}{l}\text { (a) } 2 \mathrm{hr} \text {. after pacing } \\
\text { (b) } 3 \text { days after pacing } \\
\text { (c) } 2 \mathrm{mth} \text {. after pacing } \\
\text { (a) } 1 \mathrm{hr} \text {. before pacing } \\
\text { (b) } 2 \text { days after pacing } \\
\text { (a) } 1 \mathrm{hr} \text {. before pacing } \\
\text { (b) } 1 \mathrm{wk} \text {. after pacing } \\
15 \text { min. before pacing }\end{array}$ & $\begin{array}{l}\text { Pacemaker } \\
\text { Sinus rhythm } \\
\text { Sinus rhythm } \\
\text { Complete heart block } \\
\text { Pacemaker } \\
\text { 2-to-1 heart block } \\
\text { Sinus rhythm } \\
\text { Complete heart block }\end{array}$ & $\begin{array}{l}75 \\
80 \\
86 \\
42 \\
72 \\
48 \\
75 \\
44\end{array}$ & $\begin{array}{r}30 \\
35 \\
35 \\
60 \\
25 \\
64 \\
120 \\
21\end{array}$ & $\begin{array}{l}2 \cdot 3 \\
2 \cdot 8 \\
3 \cdot 0 \\
2 \cdot 5 \\
1 \cdot 8 \\
3 \cdot 1 \\
9 \cdot 0 \\
0 \cdot 9\end{array}$ \\
\hline
\end{tabular}

there was no further arrhythmia. Steroid therapy was discontinued after 2 weeks, and after 12 weeks in hospital she returned home, though a complete cardiac invalid. She died 2 months later in congestive cardiac failure, still in sinus rhythm.

Comments. This patient had an extensive myocardial infarction. The heart block and periods of asystole produced a hazardous situation which was immediately controlled by electrode catheter pacing.

Serial cardiac output studies over a two-month period (Table III) showed a small relatively fixed stroke volume, and in these circumstances output was entirely dependent on heart rate. This explains the dramatic clinical response to pacing, despite the severe myocardial damage. It is impossible to say whether steroids helped in restoring sinus rhythm.

Patient 3 (J.B.). A 76-year-old man had intermittent claudication for five years. He developed severe gripping chest pain with breathlessness, and when seen 8 hours later he was ill and shocked with a heart rate of 50 a minute, blood pressure $90 / 50 \mathrm{~mm}$. $\mathrm{Hg}$, faint heart sounds, and basal lung crepitations. An electrocardiogram showed a posterior infarct with a 2-to-1 atrioventricular block.

He was treated with oxygen, digitalis, diuretics, and prednisolone. During the next few days his condition was unchanged and the heart rate varied with periods of sinus rhythm and 2-to-1 atrio-ventricular block. On the fourth day in hospital he developed complete heart block at a rate of 44 a minute and increasing left ventricular failure. The heart sounds were faint and the blood pressure $100 / 50 \mathrm{~mm}$. $\mathrm{Hg}$. Because of progressive deterioration in his condition, a bipolar electrode catheter was placed in the right ventricle and artificial pacing was instituted at a rate of 75 a minute. Over a 12-hour period there was marked improvement. His extremities became warm, urinary output increased, and the pulmonary congestion diminished. The heart block persisted, and on the sixth day a failure of pacing was corrected by repositioning the electrode catheter. Artificial pacing was discontinued after 8 days when normal sinus rhythm had returned. The electrode catheter was left in situ and the steroids were gradually withdrawn.

His progress was uneventful until the nineteenth day (8 days after disappearance of heart block), when he suddenly collapsed with ventricular asystole and attempted resuscitation was unsuccessful. Necropsy showed an extensive posterior infarct involving the whole thickness of the inferior ventricular wall from apex to base. A large part of the posterior septum was also infarcted. The main trunk of the right coronary artery was occluded by thrombus over a distance of $1.5 \mathrm{~cm}$. The other coronary vessels were much narrowed by calcified atheroma.

Comments. This patient had a massive infarction with persistent left ventricular failure and heart block which did not respond to medical treatment. Artificial pacing appeared to be a major factor in resolving the left ventricular failure. Circulatory studies before and after pacing (Table III) show a moderate fall in cardiac output after 48 hours of pacing associated with a marked fall in stroke volume (from $60 \mathrm{ml}$. to $25 \mathrm{ml}$. per beat). It is probable that the reduction in stroke volume produced a fall in left ventricular diastolic pressure with relief of the pulmonary venous congestion. The sudden episode of asystole underlines the need for continuous supervision of patients who have had a disturbance of rhythm after myocardial infarction.

Patient 4 (A.C.). A 74-year-old hypertensive woman had severe anterior chest pain radiating to the arms, and was admitted to hospital. The blood pressure was $125 / 100 \mathrm{~mm}$. $\mathrm{Hg}$, with faint heart sounds, an atrial triple rhythm, and basal lung crepitations. The electrocardiogram showed sinus rhythm, grade I heart block (P-R 0.28 sec.), and right bundle-branch block with an anterior infarct. She was treated with oxygen, diuretics, and intravenous hydrocortisone. Four hours later she suddenly became unconscious with an unrecordable blood pressure and a heart rate of 40 a minute caused by varying 2-to-1 and 3-to-1 atrioventricular block. Intravenous mephentermine had little effect and the systolic blood pressure did not rise above $60 \mathrm{~mm}$. $\mathrm{Hg}$. One hour later she was in a moribund condition, and a bipolar electrode catheter was inserted into the right ventricle as an emergency procedure. Pacing was begun at a rate of 80 a minute. The systolic blood pressure rose immediately to $80 \mathrm{~mm}$. $\mathrm{Hg}$, within one hour to $90 \mathrm{~mm}$. $\mathrm{Hg}$, and within four hours to $95 \mathrm{~mm}$. Hg. Her general condition gradually improved though she was still in left ventricular failure. She suddenly collapsed with complete cardiac arrest 18 
hours after pacing began. There was no response to resuscitation.

Necropsy showed a hæmopericardium with rupture of the left ventricle and an extensive antero-lateral infarct. A recent thrombus was present in the anterior descending branch of the left coronary artery and extensive atheroma of the left circumflex and right coronary arteries.

Comments. This patient had an extensive infarct with left ventricular failure, and the onset of partial heart block caused severe circulatory collapse. Artificial pacing produced immediate and dramatic improvement in her condition and her subsequent progress was satisfactory. She died from rupture of the infarcted ventricle.

Patient 5 (W.F.). A 68-year-old man developed severe constricting chest pain spreading to both arms. On admission to hospital 48 hours later the heart was coupling at a rate of 56 a minute with faint heart sounds, a blood pressure of $135 / 80 \mathrm{~mm}$. $\mathrm{Hg}$, and basal lung crepitations. The electrocardiogram showed a Wenchebach phenomenon with coupling due to conduction failure of every third beat, together with an acute posterior infarction. Two days after admission his condition deteriorated, and his heart rate fell to 45 with 2-to-1 atrio-ventricular block. There was increasing breathlessness with signs of left and right heart failure.

He was transferred to the Cardiac Unit and a bipolar electrode catheter was inserted into the outflow tract of the right ventricle. Artificial pacing was established at a rate of 75 a minute and he was started on prednisolone. His condition rapidly improved and the heart failure cleared within 18 hours. Pacing was discontinued after 4 days when normal sinus rhythm had returned. The electrode catheter was removed after a further 4 days, and the prednisolone was gradually withdrawn. His further progress was uneventful and 6 weeks after admission he returned home in sinus rhythm without any evidence of heart failure. When reviewed in the outpatient clinic two months later he was still in sinus rhythm and had mild effort angina.

Comments. The heart block became more advanced 5 days after the infarction with combined left and right heart failure and worsening of his condition. There was rapid resolution of the cardiac failure after pacing began. Circulatory studies after recovery from heart block show a marked increase in both cardiac output and stroke volume (Table III). This case illustrates the improvement in cardiac function achieved by increasing the heart rate.

Patient 6 (D.A.). A 57-year-old woman had a transient right hemiparesis 18 months before admission and was then symptom free. She then developed severe central chest pain followed by syncope and was found lying on the floor in a confusional state, with a heart rate of 40 a minute, an unrecordable blood pressure, and faint heart sounds. On admission to hospital one hour later there was no essential change. The electrocardiogram showed a developing acute posterior infarction with complete heart block and a ventricular rate of 44 . Treatment with oxygen and metaraminol was ineffective, and two and a half hours after admission she had an arterial $\mathrm{Po}_{2}$ of $70 \mathrm{~mm}$. $\mathrm{Hg}$, a base deficit of $12 \mathrm{mEq} / \mathrm{l}$. and a cardiac output of less than 11 ./min. (Table III).

A bipolar electrode catheter was positioned in the right ventricle and pacing started at a rate of 80 a minute. An intravenous infusion of 5 per cent sodium bicarbonate was started to correct the severe metabolic acidosis, but after $250 \mathrm{ml}$. had been infused over a period of five minutes, acute pulmonary œdema developed followed half a minute later by ventricular fibrillation. Defibrillation was done 14 times with ventricular fibrillation alternating with short periods of complete heart block. Eventually artificial pacing was re-established at a rate of 80 beats a minute, but there was no circulatory response and she remained in pulmonary congestion with a systolic blood pressure below $60 \mathrm{~mm}$. $\mathrm{Hg}$. Death occurred one hour later.

Necropsy showed mild mitral stenosis with a valve diameter of $2.5 \mathrm{~cm}$. A recent thrombus was present in the right coronary artery $3 \mathrm{~cm}$. from its origin. Atheroma was present in the anterior descending branch of the left coronary artery. Small areas of fibrosis were present throughout the ventricular septum. There was no macroscopical evidence of recent myocardial infarction and only minimal histological changes.

Comments. This patient developed posterior wall ischæmia and complete heart block after an acute right coronary occlusion. Artificial pacing was instituted because of a profound circulatory collapse which failed to respond to conventional treatment. The acute pulmonary œdema and subsequent ventricular fibrillation were almost certainly due to rapid infusion of sodium bicarbonate solution into a failing circulation. Although satisfactory pacing was eventually established, there was no effective mechanical cardiac contraction, presumably due to severe myocardial damage. It is possible that immediate artificial pacing may have been of benefit.

Patient 7 (H.W.). This 41-year-old man developed severe upper chest pain radiating to the jaw and left arm, and two hours later was admitted to hospital. An electrocardiogram showed sinus rhythm, right bundlebranch block, and an extensive anterior infarct. Twenty-four hours later he had further severe chest pain with a fall in blood pressure from $120 / 70$ to $70 / 50$ $\mathrm{mm}$. Hg. The electrocardiogram now showed complete heart block at a rate of 50 with a left bundle-branch block pattern. In addition, there were brief runs of ventricular tachycardia and occasional periods of complete atrio-ventricular dissociation with alternating right and left bundle-branch block. Intravenous hydrocortisone and mephentermine were without effect. His condition worsened with severe left ventricular failure and a systolic blood pressure below $70 \mathrm{~mm}$. $\mathrm{Hg}$. Eight hours after the onset of heart block an electrode catheter was inserted into the right ventricle. This produced multiple ventricular ectopic beats and 30 
seconds later ventricular fibrillation. The catheter was immediately withdrawn to the right atrium and a direct current shock converted the fibrillation to ventricular asystole. After a brief period of external cardiac massage, artificial pacing was established at a rate of 70 a minute. The blood pressure increased to $85 / 60$ $\mathrm{mm} . \mathrm{Hg}$ within several minutes and full consciousness returned without any evidence of cerebral damage. Five hours later pacing was satisfactory, the blood pressure was $90 / 60 \mathrm{~mm}$. $\mathrm{Hg}$, and his general condition had improved. On the following day he was still in left ventricular failure with a blood pressure of $85 / 60$ $\mathrm{mm}$. $\mathrm{Hg}$, an arterial oxygen saturation of 89 per cent, and a metabolic acidosis (base deficit of $6 \mathrm{mEq} / \mathrm{l}$.). After pacing for 24 hours he became progressively worse with a falling blood pressure and increasing cardiogenic shock. A few hours later there were two short bouts of ventricular tachycardia followed by ventricular fibrillation, and attempted resuscitation was unsuccessful. Necropsy showed recent thrombus in the left circumflex and anterior descending branches of the left coronary artery and the main right coronary artery was severely stenosed. There was a transmural anterior infarction affecting mainly the apex of the left ventricle.

Comments. This patient had a severe infarction complicated by heart block and left ventricular failure. The onset of ventricular fibrillation when an electrode catheter was passed into the right ventricle shows the necessity for being prepared to treat this emergency. The progressive deterioration appeared to be due to severe myocardial damage, but a more rapid rate of pacing may have suppressed the terminal dysrhythmia and improved cardiac output.

Patient 8 (C.L.). A 57-year-old woman had a myocardial infarct followed by effort angina for 3 years. She then developed severe upper chest pain associated with breathlessness and two days later was admitted to hospital. On admission she was stuporose, with a systolic blood pressure of $80 \mathrm{~mm}$. $\mathrm{Hg}$, faint heart sounds, a triple rhythm, and widespread lung crepitations. The electrocardiogram showed sinus rhythm, right bundlebranch block, and anterior infarction. Treatment with oxygen, pressor agents, digoxin, and intravenous hydrocortisone produced slight improvement.

There was sudden deterioration 5 hours after admission and the electrocardiogram now showed complete heart block at a rate of 40 a minute. Four hours after the onset of heart block she was in severe cardiogenic shock and left ventricular failure. A bipolar electrode catheter was inserted into the outflow tract of the right ventricle and artificial pacing was begun at a rate of 70 a minute. There was gradual improvement though the blood pressure remained low for 24 hours at $80 / 50 \mathrm{~mm}$. $\mathrm{Hg}$. After 26 hours of pacing normal sinus rhythm returned and pacing was stopped, but had to be resumed 15 minutes later because of ventricular asystole. Pacing was discontinued after 38 hours when she was in atrial fibrillation at 90 a minute with a blood pressure of $105 / 65 \mathrm{~mm}$. $\mathrm{Hg}$ and no longer in heart failure. The electrode catheter was removed 5 days later, when she was in sinus rhythm with a right bundle-branch block, and monitoring was discontinued. On the ninth hospital day she died suddenly. There was no necropsy.

Comments. This patient illustrates the rapid recovery from cardiogenic shock and left ventricular failure produced by artificial pacing. There was a period of unstable rhythm before pacing could be discontinued. Her sudden death, as in Patient 3, probably due to ventricular asystole or fibrillation, shows that continous monitoring is necessary for at least 3 weeks after an episode of heart block.

Patient 9 (E.B.). A 77-year-old woman suddenly developed central chest pain, effort breathlessness, and nocturnal dyspncea. When seen 4 days later, an electrocardiogram showed 2-to-1 atrio-ventricular block without any evidence of myocardial infarction. Her condition gradually worsened, and she was admitted to hospital after a further 9 days in cardiac failure. An electrocardiogram showed 2-to-1 heart block. The following day she began to have repeated Stokes-Adams seizures with complete heart block and was transferred to the Cardiac Centre.

On admission she was semi-comatose with an unrecordable blood pressure and severe left and right heart failure. An electrocardiogram showed complete heart block, ventricular ectopic beats, and brief runs of ventricular tachycardia (Fig. 1). Thirty minutes after admission, at the start of catheterization, she developed ventricular fibrillation which was immediately treated by external cardiac massage and defibrillation. A bipolar electrode catheter was then passed into the right ventricle and artificial pacing established at 80 a minute. Her condition gradually improved and there was a good diuresis. After 72 hours pacing her cardiac failure had cleared, her mental state was almost normal, and her blood pressure was $160 / 80 \mathrm{~mm}$. $\mathrm{Hg}$. Her further progress was uneventful and complete heart block necessitating artificial pacing persisted for 6 weeks. Sympathomimetic drugs were without effect. She then developed 2-to-1 atrio-ventricular block, and occasional brief periods of normal sinus rhythm with dropped ventricular complexes. The electrocardiogram now showed a healing posterior infarct (Fig. 1). Because of the persistent heart block, long-term pacing was established with an electrode catheter inserted into the right ventricle through the right external jugular vein and a subcutaneous axillary pacemaker unit (Siddons and Davies, 1963). Two months later she was well and pacing satisfactorily.

Comments. This patient with severe circulatory collapse, complete heart block, and an unstable rhythm showed an immediate response to artificial pacing.

Patient 10 (R.M.). A 68-year-old man had severe anterior chest pain and was admitted to hospital three hours later. An electrocardiogram showed sinus rhythm and left bundle-branch block. Despite treatment with morphia, oxygen, and diuretics, his 

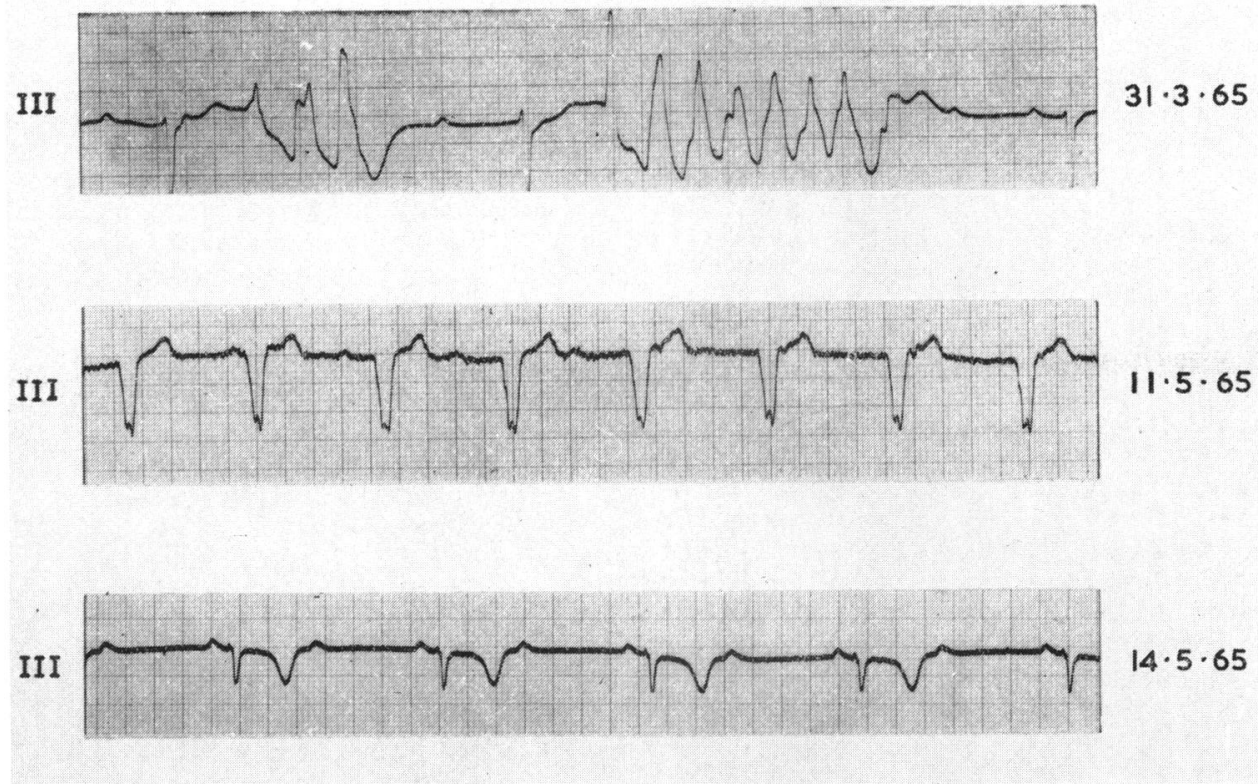

Fig. 1.-Patient 9. Serial electrocardiograph recordings lead III. Top: on admission. Complete heart block, multifocal ventricular ectopic beats, and a brief paroxysm of ventricular tachycardia. Centre: Control of rhythm by artificial pacing. The rapid initial deflection from the pacemaker is barely visible on this record. The $\mathbf{P}$ waves continue independently. Bottom: Six weeks after admission when pacing was discontinued, showing 2-to-1 atrio-ventricular block with deep $T$ wave inversion due to posterior myocardial infarction. A permanent electrode catheter was subsequently inserted.

condition progressively deteriorated. Intravenous digoxin, hydrocortisone, and metaraminol were also of no benefit. Seven hours after admission he developed complete cardiac arrest.

Immediate resuscitation was carried out by external cardiac massage and artificial ventilation, and intravenous sodium bicarbonate was infused. After 75 minutes he had complete heart block at a rate of 30 a minute. Intravenous atropine had no effect on the ventricular rate and there was no effective circulation without cardiac massage. A bipolar electrode catheter was inserted into the right ventricle and artificial pacing was established. Each pacemaker stimulus produced an electrocardiographic response but without an effective ventricular contraction. On fluoroscopy there was a small ripple of the ventricular wall near the tip of the catheter but the remainder of the ventricle was immobile. There was no circulation without external cardiac massage, and resuscitation was eventually abandoned. Necropsy showed atheroma of both coronary arteries with thrombus occluding the anterior descending branch of the left coronary artery. There was an extensive recent anterior infarct.

Comments. This patient developed severe cardiogenic shock followed by cardiac arrest. Prolonged resuscitation restored sinus rhythm with complete atrio-ventricular block but without an effective ventricular contraction. Artificial pacing was of no benefit because of the severe myocardial damage.

\section{Discussion}

Heart block is a serious complication of acute myocardial infarction since almost half the patients die (Table I). Those who survive usually recover from the heart block which appears to be only a temporary disturbance of the conduction system (Blondeau et al., 1961; James, 1962). Since a return of normal conduction is likely, it seems worth while to try and tide all such patients over the acute crisis.

The onset of heart block is likely to cause deterioration in a patient with a recent infarct. Studies of cardiac output in long-standing complete heart block have shown that a normal cardiac output can be maintained by a healthy myocardium through a compensatory increase in stroke volume (Bevegård, 1962; Judge, Wilson, and Siegel, 1964; Sowton, 1964b; McGregor and Klassen, 1964). A diseased myocardium may be incapable of increasing its stroke volume, so that changes in cardiac 
output are completely dependent on heart rate. A slow rate is then associated with a very low cardiac output (Benchimol et al., 1963; Sowton, 1964b; McGregor and Klassen, 1964). Ventricular function may be severely impaired in acute myocardial infarction since part of the muscle mass is noncontractile and mechanical efficiency is further diminished by paradoxical systolic ballooning of the area of infarction. Circulatory studies in acute myocardial infarction with sinus rhythm show that both cardiac output and stroke volume tend to be reduced, and this can be broadly related to the clinical state of the patient. The largest reduction in cardiac output is found in patients with cardiogenic shock (Lee, 1957; Broch et al., 1959; Murphy et al., 1963; Mackenzie et al., 1964).

Only one circulatory study has been reported of heart block in acute myocardial infarction (Murphy et al., 1963). This patient who was not in shock or left ventricular failure had a moderate rise in stroke volume during the period of block, which maintained a normal resting cardiac output. The cardiac output studies in 4 of our patients are summarized in Table III. Patient 2 was studied only after pacing on three occasions. There was a fixed stroke volume and cardiac output was completely dependent on rate. Patient 3 had measurements before and after pacing: he was in left ventricular failure on both occasions though less breathless after pacing began; the stroke volume showed a marked fall at the faster pacing rate. Patient 5 was studied before pacing and 12 days later when his heart failure had resolved and he was in sinus rhythm: the stroke volume had then doubled and the cardiac output had trebled. Patient 4 was in severe cardiogenic shock and in the terminal stages of circulatory failure.

Thus two kinds of circulatory change may occur if heart block complicates acute myocardial infarction. In the most seriously ill patients, cardiac output is dependent on heart rate with a fixed stroke volume and artificial pacing may produce improvement simply by speeding the heart. This appeared to be the case in Patient 2. Other patients may have a compensatory increase in stroke volume and in this way maintain the cardiac output. This was so in Patient 3 who was in some respects similar to the patient reported by Murphy et al. (1963). An increase of stroke volume seems undesirable in acute myocardial infarction, since it must stretch the damaged myocardium and predispose to ventricular rupture. It also increases left ventricular diastolic pressure and may precipitate left ventricular failure. Artificial pacing may then benefit the patient by reducing stroke volume, as in Patient 2.

Benchimol et al. (1963) and Sowton (1964b) found an optimal pacing rate between 70 and 80 a minute in hearts with myocardial disease. We arbitrarily chose this range of heart rate for pacing our patients, since there are no circulatory studies of the effects of pacing at different rates in heart block with myocardial infarction.

In some patients the heart block is part of a generalized disturbance of cardiac rhythm, and it can be associated with transient bouts of ventricular tachycardia, fibrillation, or asystole. Apart from progressive impairment of circulatory function, such patients may die suddenly from the dysrhythmia: artificial pacing will suppress the abnormal rhythms and achieve control of the situation. Patients 1,2, and 9 illustrate this problem and the dramatic effects of pacing. Smirk and Palmer (1960) and Julian et al. (1964) have described a situation predisposing to ventricular fibrillation after myocardial infarction, where premature ventricular contractions develop with the $R$ wave of the ectopic beat falling on the preceding normal $\mathrm{T}$ wave. The " $R$ on $T$ " premature beats are often followed by short bursts of ventricular tachycardia and then ventricular fibrillation. Sowton (1964b) has suggested artificial pacing to suppress the " $R$ on $T$ " beats as a matter of urgency.

Corticosteroids have been used in heart block in acute myocardial infarction to try and reduce any inflammatory reaction in the atrio-ventricular node and bundle of His and to restore normal atrioventricular conduction. Dall (1964), reporting good results with corticosteroids in 24 patients, found parenteral treatment more rapidly effective than oral. All but 3 recovered sinus rhythm, though 7 of the $24(29 \%)$ died within a month of the infarct. Of our patients, 7 had corticosteroids: 2 before heart block developed, 4 after the onset of block and before pacing, and 1 after pacing (Table II). Parenteral hydrocortisone was used in 5 and oral prednisolone in 2 patients. Steroids were gradually withdrawn after normal conduction returned. It is impossible to assess whether steroids were of any benefit, but they did not appear to have any immediate influence on these critically ill patients in the 2 to 9 hours of treatment before pacing was begun. Normal conduction returned in 4 patients after 16 hours to 8 days of pacing (Patients $2,3,5$, and 8). All were on corticosteroids and the average duration of block was $3 \frac{1}{2}$ days. Four patients died in heart block after 1 hour to 5 days of pacing (Patients 1, 4, 6, 7).

Without steroid therapy or artificial pacing, acute heart block in infarction lasts from a few hours to 14 days with return to sinus rhythm in the majority within one week (Blondeau et al., 1961; Courter et al., 1963). The patients reported by Dall (1964) 
who were given parenteral steroids had returned to sinus rhythm within 24 hours of starting treatment if they survived. Although steroids may promote the restoration of sinus rhythm, there is always a delay before they produce their effect, and a patient in heart block with cardiogenic shock or StokesAdams seizures may die suddenly during this time. In these circumstances artificial pacing may improve cardiac function and prevent circulatory arrest, and it should be used as the treatment of choice at the earliest opportunity. It is essential to have an external defibrillator available when inserting an electrode catheter, in view of our experiences with Patients 7 and 9. Continuous electrocardiographic monitoring is also necessary during the period of artificial pacing and probably for a further two or three weeks because of the risk of late sudden death (Patients 3 and 8). Late deaths 5 to 30 days after the return of sinus rhythm have also been reported by Cohen, Doctor, and Pick (1958), Blondeau et al. (1961), Courter et al. (1963), and Julian et al. (1964).

The results in this series of patients at first sight are discouraging, since 4 patients died in heart block, and of the remaining 5 patients only 3 eventually left hospital. However, all were seriously ill and in left ventricular failure and 7 had cardiogenic shock. Three patients having StokesAdams seizures were moribund when admitted to the unit, though 2 of them survived and left hospital. When the patients were assessed by the coronary prognostic index of Peel et al. (1962), all but one had a score of above 20 and therefore an expected mortality rate of 85 per cent.

Some patients appear to have irreversible myocardial damage and pacing is without benefit. In Patients 6 and 10 adequate electrical stimulation failed to produce an effective ventricular contraction. Rupture of the myocardium (Patient 4) seems to be an unavoidable risk in any severe infarction. With greater experience the technical troubles in Patient 1 and the late deaths in Patients 3 and 8 might have been prevented.

\section{Conclusions}

Patients who develop heart block during a myocardial infarction are critically ill. It may aggravate or precipitate cardiac failure and there is a risk of sudden circulatory arrest. Artificial pacing will improve cardiac function and help to resolve cardiac failure. Abnormal ventricular rhythms are suppressed and the risk of sudden circulatory arrest is diminished.

A few patients maintain an adequate circulation and are relatively undisturbed by the heart block. Artificial pacing may not be necessary unless there is deterioration despite treatment with sympathomimetic drugs and parenteral steroids. Nevertheless, such patients may die suddenly and there is a good case for establishing artificial pacing electively rather than waiting until a critical situation develops. Alternatively an electrode catheter could be positioned with its tip in the right atrium ready to be advanced into the ventricle if the need for pacing arose.

In 4 patients (Patients $2,4,7,8$ ), a right bundlebranch block with sinus rhythm was present before the onset of heart block, and in another, Patient 9, a left bundle-branch block with sinus rhythm preceded asystole and subsequent complete heart block. Since a bundle-branch block may be followed by atrio-ventricular block, these patients are at greater risk. In our view it is worth considering the insertion of catheter electrodes in any patient with acute myocardial infarction who develops a conduction defect. It is certainly clear that all such patients require continuous electrocardiographic monitoring.

\section{SUMMARY}

Ten patients are described with heart block or asystole following an acute myocardial infarction. In all these patients artificial pacing was established by an electrode catheter. Four patients died in persistent heart block with little or no response to pacing. One patient died from a ruptured ventricle after showing initial improvement with artificial pacing. Of the 5 remaining patients, 4 returned to sinus rhythm and pacing was discontinued. Of these 4,2 died suddenly after making excellent progress. The other patient remained in partial heart block and a permanent electrode catheter was inserted. Only 3 patients eventually left hospital.

Circulatory studies were carried out in 4 patients. The management of these patients is discussed.

\section{REFERENCES}

Abrams, L. D., Hudson, W. A., and Lightwood, R. (1960). A surgical approach to the management of heart-block using an inductive coupled artificial pacemaker. Lancet, $1,1372$.

Benchimol, A., Li, Y., Dimond, E. G., Voth, R. B., and Roland, A. S. (1963). Effect of heart rate, exercise, and nitroglycerin on the cardiac dynamics in complete heart block. Circulation, 28, 510 .

Bevegård, S. (1962). Observations on the effect of varying ventricular rate on the circulation at rest and during exercise in two patients with an artificial pacemaker. Acta med. scand., 172, 615.

Blondeau, M., Rizzon, P., and Lenègre, J. (1961). Les troubles de la conduction auriculo-ventriculaire dans l'infarctus myocardique récent. I. Étude clinique. Arch. Mal. Cæur, 54, 1092. 
Broch, O. J., Humerfelt, S., Haarstad, J., and Myhre, J. R. (1959). Hemodynamic studies in acute myocardial infarction. Amer. Heart F., 57, 522.

Brown, K. W. G., MacMillan, R. L., Forbath, N., Mel'grano, F., and Scott, J. W. (1963). Coronary unit. An intensive-care centre for acute myocardial infarction. Lancet, 2, 349.

Bruce, R. A., Blackmon, J. R., Cobb, L. A., and Dodge, H. T. (1965). Treatment of asystole or heart block during acute myocardial infarction with electrode catheter pacing. Amer. Heart f., 69, 460.

Chardack, W. M., Gage, A. A., Schimert, G., Thomson, N. B., Sanford, C. E., and Greatbatch, W. (1963). Two years' clinical experience with the implantable pacemaker for complete heart block. Dis. Chest, 43, 225.

Cohen, D. B., Doctor, L., and Pick, A. (1958). The significance of atrioventricular block complicating acute myocardial infarction. Amer. Heart f., 55, 215.

Courter, S. R., Moffat, J., and Fowler, N. O. (1963). Advanced atrioventricular block in acute myocardial infarction. Circulation, 27, 1034.

Dall, J. L. C. (1964). The effect of steroid therapy on normal and abnormal atrioventricular conduction. Brit. Heart F., 26, 537.

- , and Buchanan, J. (1962). Steroid therapy in heartblock following myocardial infarction. Lancet, 2, 8.

Day, H. W. (1965). Effectiveness of an intensive coronary care area. Amer. F. Cardiol., 15, 51.

Delman, A. J., Schwedel, J. B., and Escher, D. J. W. (1963). An intracardiac pacemaker in Adams-Stokes attacks in acute myocardial infarction. f. Amer. med. Ass., 184, 1040.

DeSanctis, R. W. (1963). Short-term use of intravenous electrode in heart block. F. Amer. med. Ass., 184, 544.

Furman, S., and Robinson, G. (1958). The use of an intracardiac pacemaker in the correction of heart block. Surg. Forum, 9, 245.

Gale, H. H., and Enfroy, H. L. (1959). Stokes-Adams attacks complicating acute myocardial infarction: Their treatment with continuous intravenous infusion of isopropylnorepinephrine. New Engl. F. Med., 260, 1229.

Gilchrist, A. R. (1958). Clinical aspects of high-grade heartblock. Scot. med.f., 3, 53.

Goldman, M. J. (1950). Cardiac arrhythmias in myocardial infarction. Amer. Heart f., 39, 884.

Imperial, E. S., Carballo, R., and Zimmerman, H. A. (1960). Disturbances of rate, rhythm and conduction in acute myocardial infarction. A statistical study of 153 cases. Amer. F. Cardiol., 5, 24.

James, T. N. (1962). Arrhythmias and conduction disturbances in acute myocardial infarction. Amer. Heart $\mathcal{F} ., 64,416$.

Johnson, C. C., and Miner, P. F. (1958). The occurrence of arrhythmias in acute myocardial infarctions. Dis. Chest, 33, 414.

Judge, R. D., Wilson, W. S., and Siegel, J. H. (1964). Hemodynamic studies in patients with implanted cardiac pacemakers. New Engl. F. Med., 270, 1391.

Julian, D. G., Valentine, P. A., and Miller, G. G. (1964). Disturbances of rate, rhythm and conduction in acute myocardial infarction. Amer. F. Med., 37, 915.

Landegren, J., and Biörck, G. (1963). The clinical assessment and treatment of complete heart block and AdamsStokes attacks. Medicine (Baltimore), 42, 171.
Lee, G. de J. (1957). Total and peripheral blood flow in acute myocardial infarction. Brit. Heart $\mathcal{F} ., 19,117$.

Levowitz, B. S., Ford, W. B., and Smith, J. W. (1960). The use of direct stimulating myocardial electrodes in complete atrioventricular block. f. thorac. Surg., 40, 283.

Mackenzie, G. J., Taylor, S. H., Flenley, D. C., McDonald, A. H., Staunton, H. P., and Donald, K. W. (1964). Circulatory and respiratory studies in myocardial infarction and cardiogenic shock. Lancet, 2, 825.

Master, A. M., Dack, S., and Jaffe, H. L. (1938). Partial and complete heart block in acute coronary artery occlusion. Amer.F. med. Sci., 196, 513.

McGregor, M., and Klassen, G. A. (1964). Observations on the effect of heart rate on cardiac output in patients with complete heart block at rest and during exercise. Circulat. Res., 15, Suppl. II, 215.

Mintz, S. S., and Katz, L. N. (1947). Recent myocardial infarction. An analysis of five hundred and seventytwo cases. Arch.intern. Med., 80, 205.

Murphy, G. W., Glick, G., Schreiner, B. F., and Yu, P. N. (1963). Cardiac output in acute myocardial infarction. Serial determination by precordial radioisotope dilution curves. Amer.F.Cardiol., 11, 587.

Parsonnet, V., Zucker, I. R., Gilbert, L., and Asa, M. M. (1962). An intracardiac bipolar electrode for interim treatment of complete heart block. Amer. F. Cardiol., 10,261 .

Peel, A. A. F., Semple, T., Wang, I., Lancaster, W. M., and Dall, J. L. G. (1962). A coronary prognostic index for grading the severity of infarction. Brit. Heart $\mathcal{F} ., 24$, 745.

Penton, G. B., Miller, H., and Levine, S. A. (1956). Some clinical features of complete heart block. Circulation, $13,801$.

Phelps, M. D., and Lindsay, J. D. (1957). Cortisone in Stokes-Adams disease secondary to myocardial infarction. New Engl.F. Med., 256, 204.

Portal, R. W., Davies, J. G., Leatham, A., and Siddons, A. H. M. (1962). Artificial pacing for heart-block. Lancet, 2, 1369.

Prinzmetal, M., and Kennamer, R. (1954). Emergency treatment of cardiac arrhythmias. $\mathcal{F}$. Amer. med. Ass., 154, 1049.

Robinson, J. S., Sloman, G., and McRae, C. (1964). Continuous electrocardiographic monitoring in the early stages after acute myocardial infarction. Med. $\mathcal{F}$. Aust., 1, 427.

Rosenbaum, F. F., and Levine, S. A. (1941). Prognostic value of various clinical and electrocardiographic features of acute myocardial infarction. 1. Immediate prognosis. Arch.intern. Med., 68, 913.

Rowe, J. C., and White, P. D. (1958). Complete heart block: A follow-up study. Ann. intern. Med., 49, 260.

Samet, P., Jacobs, W., and Bernstein, W. H. (1963). Electrode catheter pacemaker in the treatment of complete heart block in the presence of acute myocardial infarction. Report of four cases. Amer. F. Cardiol., 11, 379.

Siddons, H., and Davies, J. G. (1963). A new technique for internal cardiac pacing. Lancet, 2, 1204.

Smirk, F. H., and Palmer, D. G. (1960). A myocardial syndrome. With particular reference to the occurrence of sudden death and of premature systoles interrupting antecedent $\mathrm{T}$ waves. Amer. F. Cardiol., 6, 620.

Sowton, E. (1964a). The use of artificial pacemaking in cardiac resuscitation. Proc. roy. Soc. Med., 57, 368. 
- (1964b). Hæmodynamic studies in patients with artificial pacemakers. Brit. Heart f., 26, 737.

Veall, N., and Vetter, H. (1958). Radioisotope Techniques in Clinical Research and Diagnosis. Butterworth, London.

Vogel, J. H. K. (1961). Use of isoproterenol in the treatment of complete heart block complicating acute myocardial infarction. Amer. F. Cardiol., 7, 746.

Wright, J. C., Hejtmancik, M. R., Herrmann, G. R., and Shields, A. S. (1956). A clinical study of complete heart block. Amer. Heart f., 52, 369.

Zucker, I. R., Parsonnet, V., Gilbert, L., and Asa, M. (1963). Dipolar electrode in heart block. f. Amer. med. Ass., $184,549$.

\section{ADDENDUM}

Since this paper was submitted for publication catheter electrodes have been inserted in a further 11 patients with acute myocardial infarction.

In five patients the heart block was successfully treated by artificial pacing, and sinus rhythm returned. Two patients died later from progressive heart failure and three survived. Another three patients were artificially paced following resuscitation for cardiac arrest (two with complete heart block and one with asystole) and all of them died. Catheter electrodes were inserted prophylactically in three patients with partial heart block but all recovered without being paced. 